\title{
suPAR as a marker of infection in acute kidney injury - a prospective observational study
}

\author{
Anna Hall', Siobhan Crichton ${ }^{2}$, Matt Varrier ${ }^{3}$, Danielle E. Bear ${ }^{4}$ and Marlies Ostermann ${ }^{3,5^{*}}$ (D)
}

\begin{abstract}
Background: Soluble urokinase-type plasminogen activator receptor (suPAR) has emerged as a new sepsis biomarker. It is not known whether suPAR has a role in critically ill patients with severe acute kidney injury (AKI).

Methods: Our main aims were to describe serial serum suPAR concentrations in patients with severe AKI, to investigate a potential association between suPAR and C-reactive protein (CRP), and to compare suPAR and CRP as diagnostic markers of infection in patients with AKI. Between April 2013 - April 2014, we recruited adult patients ( $\geq 18$ years) with AKI KDIGO stage 2/3 admitted to a multidisciplinary Intensive Care Unit (ICU) in a University Hospital in UK. Serial serum suPAR and CRP concentrations were measured for 6 days. We compared the characteristics and serial suPAR and CRP concentrations of patients with and without an infection using Chi-squared, Fisher's exact, t-test and Mann-Whitney tests as appropriate, and calculated the area under the receiver operating characteristics curve (AUC).
\end{abstract}

Results: Data of 55 patients with AKI stage 2/3 were analysed (62\% male; mean age 60.5) of whom 43 patients received continuous renal replacement therapy. suPAR was not detectable in effluent fluid.

There was no significant correlation between daily suPAR and CRP concentrations. In patients with an infection, suPAR results were significantly higher than in those without an infection across all time points; there was no significant difference in CRP levels between both groups. After exclusion of patients with an infection before or on day of admission to ICU, the AUC of suPAR for predicting an infection later was 0.62 ( $95 \% \mathrm{Cl} 0.43-0.80$ ) compared to 0.50 ( $95 \% \mathrm{Cl} 0.29-0.71$ ) for CRP.

Conclusions: In critically ill patients with AKI stage 2/3, suPAR is a better marker of infection than CRP.

Trial registration: The study was retrospectively registered on the ISRCTN registry on 25 November 2012 (ISRCTN88354940).

Keywords: Acute kidney injury, suPAR, uPAR, Infection, CRP, Soluble urokinase-type plasminogen activator receptor

\section{Background}

Acute kidney injury (AKI) affects $>50 \%$ of patients in the intensive care unit (ICU) [1]. It is associated with an increased risk of complications and mortality. Sepsis is particularly common but can be challenging to diagnose due to potentially misleading clinical signs and a limited number of confirmatory diagnostic tests in routine clinical practice [2].

\footnotetext{
* Correspondence: Marlies.Ostermann@gstt.nhs.uk

${ }^{3}$ King's College London, Guy's \& St Thomas' NHS Foundation Trust,

Department of Critical Care, London SE1 9RT, UK

5King's College London, Guy's and St Thomas' Foundation Hospital,

Department of Critical Care, London SE1 7EH, UK

Full list of author information is available at the end of the article
}

Over 150 sepsis biomarkers have been identified [3]. C-reactive protein (CRP) is used mainly as a marker of inflammation. Measuring and charting CRP values can prove useful in determining disease progress or the effectiveness of treatments but it has limited ability to distinguish sepsis from other inflammatory conditions [3, 4]. Soluble urokinase-type plasminogen activator receptor (suPAR) is one of several newer sepsis markers that has been investigated in recent years [5-8]. SuPAR is the soluble form of the cell membrane-bound urokinase plasminogen activator receptor (UPAR) which is expressed on various cell types, including neutrophils, lymphocytes, monocytes, endothelial cells and tumour cells. After cleavage from the cell surface, suPAR is released into the blood

(c) The Author(s). 2018 Open Access This article is distributed under the terms of the Creative Commons Attribution 4.0 International License (http://creativecommons.org/licenses/by/4.0/), which permits unrestricted use, distribution, and 
and most human body fluids. When inflammatory cells are activated by cytokines, the expression of UPAR is up-regulated, thus increasing the serum levels of suPAR, too [9].

Several studies have shown higher systemic suPAR concentrations in critically ill patients compared to healthy controls, and in patients with infections compared to those without $[5,7,8,10]$. However, a systematic review of relevant papers published until May 2011 reported that the diagnostic value of suPAR was low in critically ill patients with sepsis [11]. A subsequent meta-analysis in 2016 concluded that suPAR had a role as a biomarker for the diagnosis and prognosis of bacterial infections but was relatively ineffective for differentiating sepsis from systemic inflammation [12]. Both meta-analyses were limited by inclusion of heterogenous patient populations with varying acute and chronic illnesses. Whether there is a role for suPAR in critically ill patients with $\mathrm{AKI}$ is unknown.

\section{Methods \\ Aims}

The aims of our study were: a) to describe serial systemic suPAR values in patients with severe AKI, including patients on continuous renal replacement therapy (CRRT); b) to explore whether suPAR was removed during CRRT; c) to investigate a potential association between suPAR and CRP, and d) to compare suPAR and CRP as diagnostic markers of infection in patients with AKI.

\section{Design}

We performed a prospective observational study between April 2013 and April 2014.

\section{Setting}

Guy's \& St Thomas' NHS Foundation Hospital is a tertiary care centre with a 43-bed, level 3 multi-disciplinary adult intensive care unit (ICU).

\section{Patient population}

We recruited critically ill adult patients ( $\geq 18$ years) with AKI stage 2 or 3 as per serum creatinine criteria of the Kidney Disease Improving Global Outcome classification [13]. The lowest serum creatinine in the preceding 12 months prior to hospitalisation was used as a baseline value; if not available, patients were excluded. Other exclusion criteria were: AKI stage $2 / 3$ present for more than $36 \mathrm{~h}$, pre-existing dialysis dependent renal failure, or an expected life expectancy $<48 \mathrm{~h}$. We also excluded patients in whom serial blood sampling was not desirable (ie. Jehovah's witness, patients with haemoglobin $<70 \mathrm{~g} / \mathrm{L})$.

\section{Collection of samples}

Samples for serum suPAR were collected at baseline and 22-26 h, 46-50 h, 94-98 h and 142-146 h after enrolment. Serum CRP was measured daily throughout the 6-day study period. In patients receiving CRRT, effluent samples were collected at the same time points for measurement of suPAR. All samples were processed and stored in dedicated research freezers at $-80{ }^{\circ} \mathrm{C}$ until batch analysis at the end of the study.

\section{Collection of clinical data}

We collected baseline demographics, Acute Physiology and Chronic Health Evaluation (APACHE) II score and Sequential Organ Failure Assessment (SOFA) score on admission to ICU. Patients were categorised as having an infection if they had documented clinical signs combined with positive microbiology or imaging results supporting the diagnosis of an infection.

\section{Laboratory analyses}

Serial suPAR concentrations were measured by enzymelinked immunosorbent assay (ELISA) using the commercially available suPARnostic ${ }^{\circ}$ ELISA Kit manufactured by ViroGates, Denmark. Samples were tested in singlets with inter-plate variation of $6 \%$. CRP was measured using a latex enhanced immunoturbidimetric method on the Siemens Advia 2400 [analytical range: $4-336 \mathrm{mg} / \mathrm{L}$ and reference range: $<10 \mathrm{mg} / \mathrm{L}]$.

\section{Statistics}

Patient characteristics, suPAR and CRP levels were summarised as frequency (percentage), mean [standard deviation (SD)] or median [interquartile range (IQR)], as appropriate. The relationship between suPAR and CRP at each time point was explored using Pearson correlation. Additionally, the correlations between suPAR and previous day CRP, CRP and previous day suPAR, and changes of suPAR and CRP from their respective previous measurement were calculated.

We compared the characteristics of patients who did and did not develop infections using the Chi-squared, Fisher's exact and t-tests, as approriate. SuPAR and CRP levels of both groups were compared using Mann-Whitney tests, and areas under the receiver operating characteristics curves (AUC) were calculated to assess the ability of suPAR and CRP to discriminate between patients with an established infection and those who did not develop an infection during the study period.

\section{Results}

We analysed the data of 55 patients with AKI stage 2 or 3 of whom 43 received CRRT during the 6-day study period. The mean age was 60.5 (15.9) years and $61.8 \%$ 
were male (Table 1$)$. The majority were caucasian $(60 \%)$, followed by Afro-Carribean (16.4\%) and Asian (10.9\%).

\section{Biomarker results}

Mean CRP levels increased between day of recruitment and day 1 and then declined from day 3 onwards (Table 2 and Fig. 1). In contrast, the systemic suPAR levels tended to remain stable or increase slighty across the 6-day study period (Table 2 and Fig. 2). In patients treated with CRRT, suPAR was not detectable in the effluent fluid.

\section{Correlation between suPAR and CRP}

On the day of enrolment (ie. day 0), there was a weak to moderate correlation between systemic suPAR and CRP concentrations $(r=0.234)$ but this was not statistically

Table 1 Baseline demographics

\begin{tabular}{ll}
\hline Parameter & Total cohort $(n=55)$ \\
\hline Age [years], mean (SD) & $60.5(15.9)$ \\
Male gender, n (\%) & $34(61.8 \%)$ \\
Ethnicity & \\
Caucasian & $60 \%$ \\
Afro-Caribbean & $16.4 \%$ \\
Asian & $10.9 \%$ \\
Other & $12.7 \%$ \\
Diabetes Mellitus & $18(32.7 \%)$ \\
Any CKD & $19(34.6 \%)$ \\
CKD stages & \\
1 & 0 \\
2 & $2(3.6 \%)$ \\
3a & $7(12.7 \%)$ \\
3b & $7(12.7 \%)$ \\
4 & $2(3.6 \%)$ \\
5 & $1(1.8 \%)$ \\
ICU admission diagnosis, $n$ (\%) & \\
Post-major surgery & $19(34.5 \%)$ \\
Sepsis & $16(29 \%)$ \\
Respiratory failure & $6(10.9 \%)$ \\
Vasculitis & $2(3.6 \%)$ \\
Multi-organ failure & $4(7.2 \%)$ \\
Neurological emergency & $2(3.6 \%)$ \\
Cardiac arrest & $1(1.8 \%)$ \\
\hline Other & $5(9.1 \%)$ \\
\hline Severity of illness on admission to ICU & \\
SPCore, mean (SD) & $19.4(5.2)$ \\
\hline
\end{tabular}

Abbreviations: APACHE Acute Physiology and Chronic Health Evaluation, CKD chronic kidney disease, SD standard deviation, SOFA sequential organ failure assessment, ICU Intensive care unit
Table 2 Correlations between mean systemic suPAR and CRP values

\begin{tabular}{llll}
\hline & $\begin{array}{l}\text { suPAR [ng/ml] } \\
\text { mean (SD) }\end{array}$ & $\begin{array}{l}\text { CRP [mg/L] } \\
\text { mean (SD) }\end{array}$ & Correlation \\
\hline Day of enrolment & $11.0(7.6)$ & $176.0(113.2)$ & $r=0.234 p=0.095$ \\
Day 1 & $11.7(7.7)$ & $199.5(106.0)$ & $r=0.092 p=0.519$ \\
Day 2 & $12.5(8.9)$ & $195.5(105.6)$ & $r=0.018 p=0.897$ \\
Day 3 & - & $160.2(88.5)$ & \\
Day 4 & $12.6(9.0)$ & $142.3(88.0)$ & $r=0.012 p=0.935$ \\
Day 5 & - & $126.1(80.6)$ & \\
Day 6 & $13.4(9.0)$ & $115.6(74.2)$ & $r=0.039 p=0 . .801$ \\
\hline
\end{tabular}

Abbreviations: sUPAR soluble urokinase-type plasminogen activator receptor, CRP C-reactive protein, $r$ regression, $S D$ standard deviation

significant $(p=0.095)$ (Table 2 and Fig. 3). After day 0 , there was no significant correlation between CRP and suPAR results.

To allow for the possibility that CRP or suPAR concentrations changed at different rates, the correlations between values on consecutive days were calculated. No significant correlation between CRP and suPAR concentrations was detected (Table 3). However, when evaluating the change in suPAR and CRP values from the respective previous measurement, a weak correlation between change in suPAR and CRP from day 0 to day 1 $(r=0.298, p=0.037)$ and day 1 to day $2(r=0.310, p=$ 0.029 ) was noted (Table 3 ). There was no correlation at any later time point.

\section{Role of suPAR and CRP as markers of infection}

There were no significant baseline differences between patients with and without an infection during the 6-day study period (Table 4). Values of suPAR were significantly higher in those with an infection across all time points but there was no difference in CRP results (Table 5). In patients with an infection, the respective AUCs of suPAR on the day of infection were higher than those of CRP values (Table 6).

\section{Role of suPAR and CRP as predictors of infection}

The majority of infections were diagnosed before of shortly after admission to the ICU. Thirty six patients had an infection during the study period of whom 5 (13.9\%) were diagnosed prior to enrolment and 13 (36\%) on day of enrolment; the remaining 18 patients $(50 \%)$ were diagnosed later. Following exclusion of patients with an infection before or on day of ICU admission, the AUC of suPAR on day 0 for predicting an infection later was $0.62(95 \%$ CI $0.43-0.80)$ compared to $0.50(0.29$ 0.71) for CRP. 


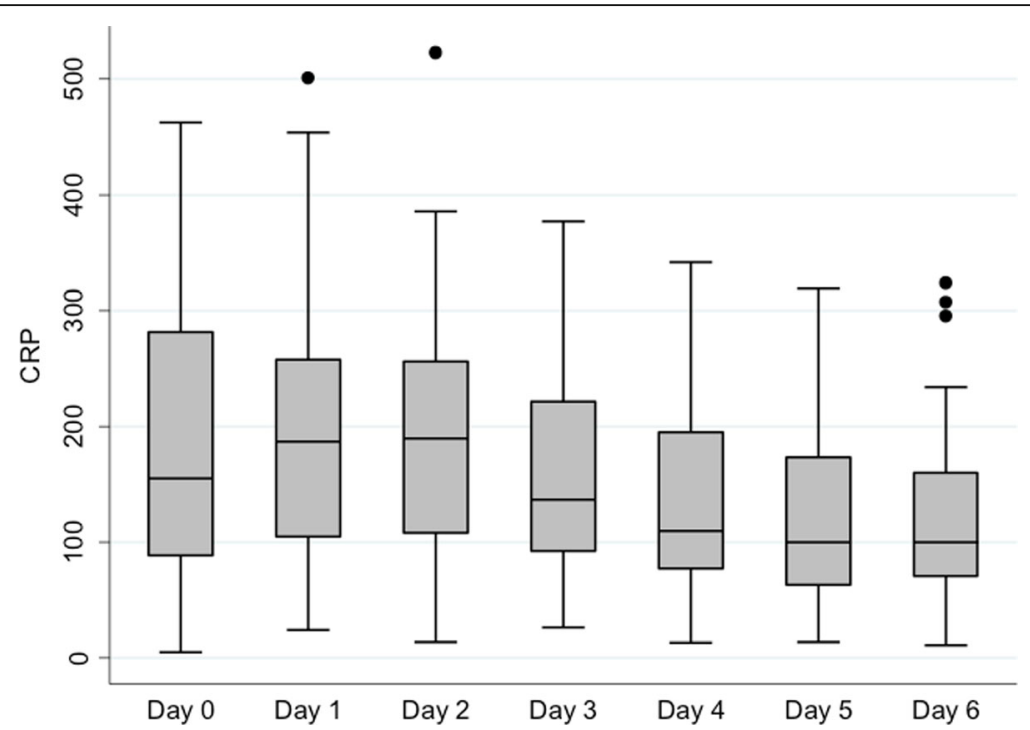

Fig. 1 Serial serum CRP concentrations. Abbreviations: $C R P=C$-reactive protein

\section{Discussion}

Our results show that CRP was a poor marker of infection in patients with severe AKI whereas suPAR had a stronger association with the development of an infection. We also confirmed that serum suPAR was not removed during CRRT.

Infections are the major causes of morbidity and mortality in patients with AKI [14]. Accurate and timely diagnosis is essential to enable clinicians to initiate appropriate and effective antimicrobial therapy early. The tools used by clinicians, namely clinical signs, inflammatory markers and imaging techniques, have important limitations [15].
SuPAR has emerged as a potential sepsis biomarker $[2,5$, 6]. Under normal physiological conditions, suPAR is predominantly expressed by neutrophils, monocytes, macrophages and activated T-cells, and its serum concentration is relatively stable throughout the day [9]. In healthy adults, mean suPAR concentrations of $2000 \mathrm{pg} / \mathrm{ml}$ have been reported [16]. SUPAR has a molecular mass of approximately 55-60 kDa. While the membrane-bound uPAR appears to facilitate phagocytosis of bacteria, suPAR has chemotactic properties and facilitates recruitment of neutrophils and monocytes [8, 11, 17, 18]. Apart from infections, serum concentrations of suPAR may also be increased during inflammatory conditions, such as

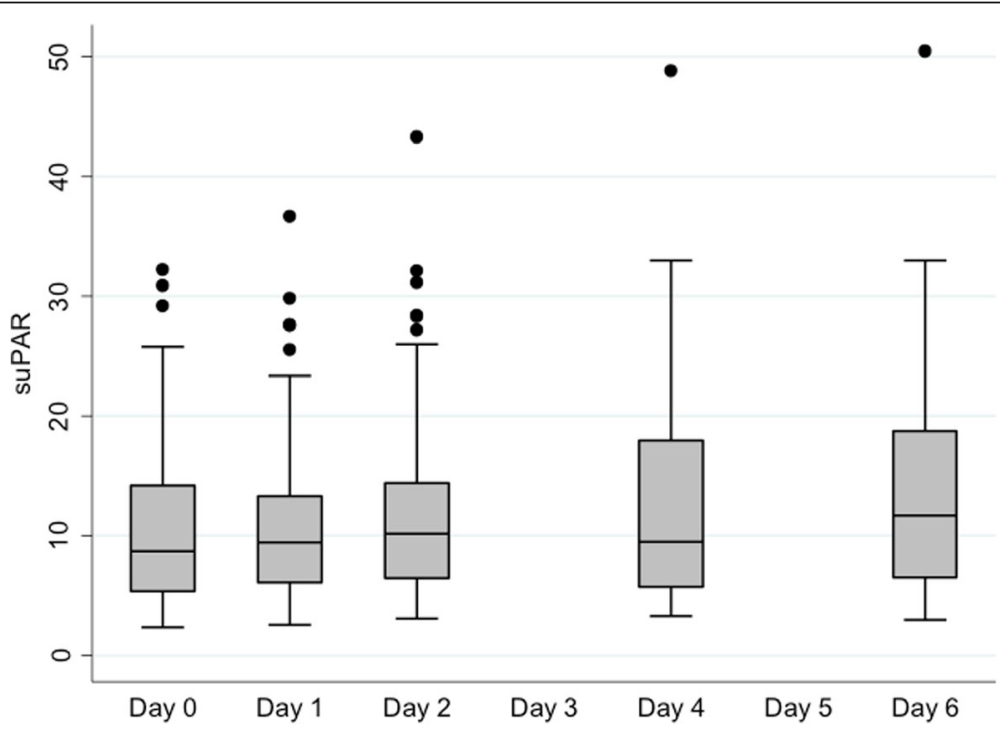

Fig. 2 Serial systemic suPAR concentrations. Abbreviations: suPAR = soluble urokinase-type plasminogen activator receptor 

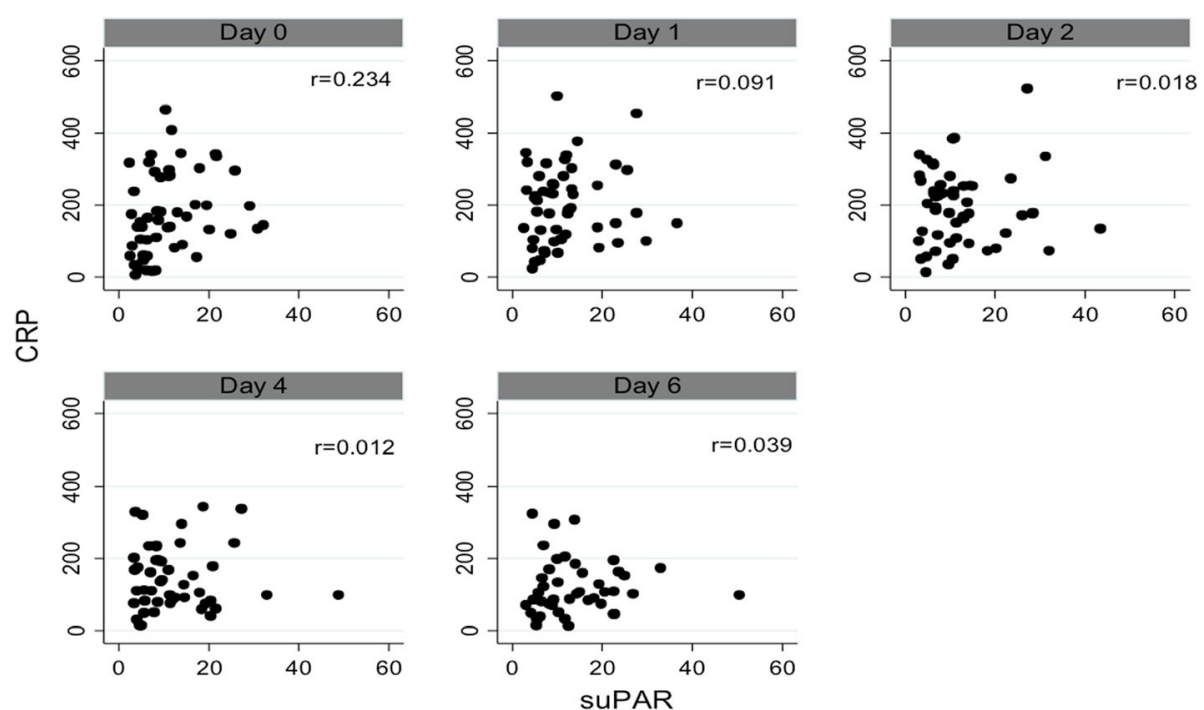

Fig. 3 Scatter plots of daily suPAR and CRP values. Abbreviations: suPAR = soluble urokinase-type plasminogen activator receptor in $\mathrm{ng} / \mathrm{ml}$; $\mathrm{CRP}=$ C-reactive protein in $\mathrm{mg} / \mathrm{L}$

arthritis, cancer and liver disease [9]. Not surprisingly, several studies have shown that critically ill patients with systemic inflammatory response syndrome (SIRS), bacteraemia or sepsis had significantly higher suPAR results than healthy controls but the accuracy of suPAR to differentiate sepsis from SIRS was low $[5,12,19-22]$.

Data on the role of suPAR in patients with renal disease are limited to patients with specific types of chronic kidney disease (CKD) like focal segmental glomerulosclerosis, diabetic nephropathy and lupus nephritis where plasma suPAR appears to have a pathological role resulting in proteinuria and renal scarring [23-26]. In a recent prospective observational trial in 107 consecutive elective cardiac surgery patients, suPAR levels were predictive of the development of AKI after surgery after exclusion of patients with pre-existing CKD [27]. Finally, in patients with cardiovascular risk factors,

Table 3 Correlations between systemic suPAR and CRP values on different days

\begin{tabular}{llll}
\hline $\begin{array}{l}\text { Correlation between } \\
\text { suPAR result and } \\
\text { previous day CRP } \\
\text { value }\end{array}$ & $\begin{array}{l}\text { Correlation between } \\
\text { CRP value and } \\
\text { previous day suPAR } \\
\text { result }\end{array}$ & $\begin{array}{l}\text { Correlation between } \\
\text { change in SUPAR and } \\
\text { change in CRP values }\end{array}$ \\
\hline Day $1 \quad r=0.228 p=0.108$ & $r=0.042 p=0.767$ & $r=0.298 p=0.037$ \\
Day $2 r=-0.026 p=0.856$ & $r=0.090 p=0.518$ & $r=0.310 p=0.029$ \\
Day $3-$ & $r=-0.104 p=0.491$ & - \\
Day $4 \quad r=-0.049 p=0.747$ & - & $r=0.232 p=0.129$ \\
Day $5-$ & $r=0.036 p=0.819$ & - \\
Day $6 r=0.048 p=0.761$ & - & $r=-0.166 p=0.299$
\end{tabular}

Abbreviations: suPAR soluble urokinase-type plasminogen activator receptor, $C R P$ C-reactive protein, $r$ regression
suPAR levels have been found to be associated with a more rapid decline in glomerular filtration rate [23].

This is the first study that focused on the role of suPAR as a marker of infection in patients with severe AKI. The main result was that suPAR only had moderate sensitivity and specificity but performed better than CRP. This is an important finding since CRP is often used in clinical practice as an aid to diagnose and monitor the course of an infection. We acknowledge that further research is necessary to confirm these findings. It will also be important to compare the performance of suPAR with that of procalcitonin (PCT), and to evaluate

Table 4 Characteristics of patients with and without infection

\begin{tabular}{|c|c|c|c|}
\hline Parameter & $\begin{array}{l}\text { No infection during } \\
\text { 6-day study period } \\
n=19\end{array}$ & $\begin{array}{l}\text { Infection during } \\
\text { 6-day study period } \\
n=36\end{array}$ & $p$-value \\
\hline Age, mean (SD) & $61.5(16.7)$ & $60.0(15.7)$ & 0.75 \\
\hline Male sex, n (\%) & $12(63.2)$ & $22(31.1)$ & 0.88 \\
\hline \multicolumn{4}{|l|}{ Ethnicity, n (\%) } \\
\hline Caucasian & $11(57.9)$ & $22(61.1)$ & 0.69 \\
\hline Afro-Carribean & $4(21.1)$ & $5(13.9)$ & \\
\hline Asian & $1(5.3)$ & $5(13.9)$ & \\
\hline Other & $3(15.8)$ & $4(11.1)$ & \\
\hline BMI, mean (SD) & $27.4(5.5)$ & $29.2(8.9)$ & 0.46 \\
\hline $\begin{array}{l}\text { SOFA score on } \\
\text { admission to ICU, } \\
\text { median (IQR) }\end{array}$ & $8(7-10)$ & $8(7-9)$ & 0.43 \\
\hline Diabetes Mellitus & $4(21.1)$ & $14(38.9)$ & 0.23 \\
\hline Any CKD & $7(36.8)$ & $12(33.3)$ & 0.99 \\
\hline
\end{tabular}
range, $S D$ standard deviation 
Table 5 Comparison of suPAR and CRP values in patients with and without infections

\begin{tabular}{|c|c|c|c|c|c|c|c|c|c|c|}
\hline & \multicolumn{5}{|c|}{ suPAR [ng/ml] } & \multicolumn{5}{|c|}{ CRP [mg/L] } \\
\hline & \multicolumn{2}{|c|}{$\begin{array}{l}\text { No infection during } 6 \text { day } \\
\text { study period }\end{array}$} & \multicolumn{2}{|c|}{$\begin{array}{l}\text { Infection during } 6 \text { day } \\
\text { study period }\end{array}$} & \multirow[t]{2}{*}{$p$-value } & \multicolumn{2}{|c|}{$\begin{array}{l}\text { No infection during } 6 \text { day } \\
\text { study period }\end{array}$} & \multicolumn{2}{|c|}{$\begin{array}{l}\text { Infection during } 6 \text { day } \\
\text { study period }\end{array}$} & \multirow[t]{2}{*}{$p$-value } \\
\hline & $n$ & Median (IQR) & $n$ & Median (IQR) & & $n$ & Median (IQR) & $n$ & Median (IQR) & \\
\hline Day of enrolment & 19 & $6.2(4.2-9.2)$ & 36 & $11.0(6.5-16.1)$ & 0.02 & 16 & $124(60-238)$ & 36 & $162(105-286)$ & 0.50 \\
\hline Day 1 & 19 & $7.2(4.5-10.1)$ & 35 & $11.4(7.1-14.5$ & 0.02 & 18 & $181(80-241)$ & 35 & $191(118-280)$ & 0.33 \\
\hline Day 2 & 18 & $8.1(3.9-11.3)$ & 34 & $10.8(6.8-14.6)$ & 0.04 & 19 & $171(51-282)$ & 35 & $204(121-254)$ & 0.49 \\
\hline Day 3 & & & & & & 16 & $125(67-212)$ & 32 & $174(98-227)$ & 0.32 \\
\hline Day 4 & 17 & $6.7(4.1-10.6)$ & 34 & $11.7(8.2-18.5)$ & 0.02 & 17 & 135 (74-202) & 31 & $109(82-178)$ & 0.94 \\
\hline Day 5 & & & & & & 15 & $98(46-196)$ & 30 & $105(63-169)$ & 0.85 \\
\hline Day 6 & 18 & $8.4(5.3-14.1)$ & 30 & $12.6(8.2-22.4)$ & 0.04 & 15 & $89(71-184)$ & 32 & $101(61-153)$ & 0.65 \\
\hline
\end{tabular}

Abbreviations: suPAR soluble urokinase-type plasminogen activator receptor, CRP C-reactive protein, IQR interquartile range

the role of suPAR in combination with existing severity of illness scores.

We acknowledge other potential limitations. First, as a single centre study, there is reduced generalisability of the results to centres with a different patient-case mix. Second, we categorised patients as having an infection based on a retrospective review of all clinical data, laboratory results and microbiological reports. It is possible that patients with an infection were missed or mis-classified. Third, suPAR concentrations can be affected by other inflammatory conditions, cancer and liver disease. In our analysis, we did not control for these potential confounders. Fourth, we only enrolled patients with AKI stage 2 and 3 and did not distinguish between different types and aetiologies of AKI, and it is possible that the performance of suPAR varies depending on the aetiology or stage of AKI. Finally, our sample size was relatively small. Larger studies are necessary to validate our findings, to determine a diagnostic cut-off of suPAR in patients with AKI and to explore whether suPAR levels correlate with the clinical course following an infection.

Table 6 Area under the receiver operating curves of suPAR and CRP for diagnosing an established infection

\begin{tabular}{|c|c|c|c|c|c|c|}
\hline & \multicolumn{3}{|c|}{ SUPAR } & \multicolumn{3}{|c|}{ CRP } \\
\hline & $n$ & AUC & $95 \% \mathrm{Cl}$ & $n$ & AUC & $95 \% \mathrm{Cl}$ \\
\hline Day 0 & 43 & 0.73 & $0.57-0.89$ & 40 & 0.58 & $0.39-0.77$ \\
\hline Day 1 & 42 & 0.72 & $0.56-0.89$ & 41 & 0.58 & $0.40-0.77$ \\
\hline Day 2 & 44 & 0.69 & $0.52-0.56$ & 45 & 0.54 & $0.35-0.73$ \\
\hline Day 3 & & & & 42 & 0.58 & $0.38-0.77$ \\
\hline Day 4 & 47 & 0.71 & $0.55-0.87$ & 45 & 0.48 & $0.29-0.68$ \\
\hline Day 5 & & & & 42 & 0.49 & $0.29-0.68$ \\
\hline Day 6 & 48 & 0.674 & $0.51-0.83$ & 47 & 0.46 & $0.27-0.65$ \\
\hline
\end{tabular}

Abbreviations: sUPAR soluble urokinase-type plasminogen activator receptor, $C R P$ C-reactive protein, $\mathrm{Cl}$ confidence interval, $A U C$ area under receiver operating characteristics curve

\section{Conclusions}

Our study showed that suPAR concentrations had better diagnostic and predictive value than CRP to detect infections in critically ill patients with severe AKI. Larger studies are necessary to confirm our findings.

\section{Abbreviations}

AKI: Acute kidney injury; APACHE: Acute Physiology and Chronic Health Evaluation; AUC: Area under receiver operating characteristics curve; BMI: Body mass index; Cl: Confidence interval; CKD: Chronic kidney disease; CRP: C-reactive protein; CRRT: Continuous renal replacement therapy; ELISA: Enzyme-linked immunosorbent assay; ICU: Intensive care unit; IQR: Interquartile range; PCT: Procalcitonin; REC: Research Ethics Committee; RRT: Renal replacement therapy; SD: Standard deviation; SIRS: Systemic inflammatory response syndrome; SOFA: Sequential organ failure assessment; suPAR: Soluble urokinase-type plasminogen activator receptor;

UPAR: Urokinase plasminogen activator receptor

\section{Acknowledgements}

We would like to thank the research nurses for recruiting the patients and collecting the samples. We would also like to thank Ms. Helle Fisker and Mr. Tomasz Pielak for performing the suPAR measurements.

\section{Funding}

The study was funded through a research grant from the European Society of Intensive Care Medicine. The funding body had no involvement in the design of the study and collection, the analysis and interpretation of data and in writing the manuscript.

\section{Availability of data and materials}

The datasets used and/or analysed during the current study are available from the corresponding author on reasonable request.

\section{Authors' contributions}

MO conceived and led the study. DB, MV and AH collected the data. SC performed the statistical analyses. All authors interpreted the results. AH wrote the first draft and all authors revised it. All authors approved the final draft.

\section{Ethics approval and consent to participate}

The study was approved by the national Research Ethics Committee (REC) London - Camberwell St Giles (REC number 13/LO/0064) and the institutional Research \& Development Department. If a patient had capacity to consent, written informed consent was obtained prior to enrolment. If a patient did not have capacity, the opinion of a personal consultee was sought in accordance with section 32 of the Mental Capacity Act 2005 (UK). In this case, patients were asked to give informed written consent confirming their willingness to continue participation once they had regained capacity. If retrospective consent was declined, all collected samples and data were discarded. In case retrospective consent could not be obtained due to death or lack of capacity, the REC felt it appropriate that these patients were included in the analysis. 


\section{Consent for publication}

Not applicable.

\section{Competing interests}

The authors declare that they have no competing interests.

\section{Publisher's Note}

Springer Nature remains neutral with regard to jurisdictional claims in published maps and institutional affiliations.

\section{Author details}

'Guy's \& St Thomas' NHS Foundation Trust, Department of Critical Care, London SE1 9RT, UK. ${ }^{2}$ MRC Clinical Trials Unit, University College London, London WC2B 6NH, UK. ${ }^{3}$ King's College London, Guy's \& St Thomas' NHS Foundation Trust, Department of Critical Care, London SE1 9RT, UK. ${ }^{4}$ Guy's \& St Thomas' NHS Foundation Trust, Departments of Nutrition and Dietetics \& Critical Care, London SE1 9RT, UK. 'King's College London, Guy's and St Thomas' Foundation Hospital, Department of Critical Care, London SE1 7EH, UK.

Received: 1 October 2017 Accepted: 23 July 2018

Published online: 02 August 2018

\section{References}

1. Hoste EA, Bagshaw SM, Bellomo R, Cely CM, Colman R, Cruz DN, et al. Epidemiology of acute kidney injury in critically ill patients: the multinational AKI-EPI study. Intensive Care Med. 2015;41(8):1411-23.

2. Sandquist M, Wong HR. Biomarkers of sepsis and their potential value in diagnosis, prognosis and treatment. Expert Rev Clin Immunol. 2014; 10(10):1349-56.

3. Vincent $\mathrm{L}$, Donadello K, Schmit X. Biomarkers in the critically ill patient: Creactive protein. Crit Care Clin. 2011;27(2):241-51.

4. Pierrakos C, Vincent JL. Sepsis biomarkers: a review. Crit Care. 2010;14(1):R15

5. Koch A, Voigt S, Krschinski C, Sanson E, Dückers H, et al. Circulating soluble urokinase plasminogen activator receptor is stably elevated during the first week of treatment in the intensive care unit and predicts mortality in critically ill patients. Crit Care. 2011;15:R63.

6. Gustafsson A, Ljunggren L, Bodelsson M, Berkestedt I. The prognostic value of sUPAR compared to other inflammatory markers in patients with severe sepsis. Biomark Insights. 2012;7:39-44.

7. Huttenen R, Syrjanen J, Vuento R, Hurme M, Huhtala H, Laine J, et al. Plasma level of soluble urokinase-type activator receptor as a predictor of disease severity and case fatality in patients with bacteraemia: a prospective cohort study. J Intern Med. 2011;270:32-40.

8. Donadello K, Scolletta S, Taccone FS, Covajes C, Santonocito C. Soluble urokinase-type plasminogen activator receptor as a prognostic biomarker in critically ill patients. J Crit Care. 2014;29(1):144-9.

9. Desmedt S, Desmedt V, Delanghe J, Speeckaert R, Speeckaert M. The intriguing role of soluble urokinase receptor in inflammatory diseases. Crit Rev Clin Lab Sci. 2017:54(2):117-33.

10. Galliera E, Drago L, Marazzi MG, Romanò C, Vassena C, Corsi Romanelli MM. Soluble urokinase-type plasminogen activator receptor (suPAR) as new biomarker of the prosthetic joint infection: correlation with inflammatory cytokines. Clin Chim Acta. 2015;20(441):23-8.

11. Backes Y, van der Sluijs KF, Mackie DP, Tacke F, Koch A. Usefulness of suPAR as a biological marker in patients with systemic inflammation or infection: a systematic review. Intensive Care Med. 2012;38(9):1418-28.

12. Ni W, Han Y, Zhao J, Cui J, Wang K, Wang R, et al. Serum soluble urokinase-type plasminogen activator receptor as a biological marker of bacterial infection in adults: a systematic review and meta-analysis. Sci Rep. 2016;6:39481.

13. Kidney Disease: Improving Global Outcomes (KDIGO) Acute Kidney Injury Work Group. KDIGO clinical practice guideline for acute kidney injury. Kidney Int. 2012;2:1-138.

14. Rewa O, Bagshaw S. Acute kidney injury - epidemiology, outcomes and economics. Nat Rev Nephrol. 2014;10(4):193-207.

15. Lu XL, Xiao ZH, Yang MY, Zhu YM. Diagnostic value of serum procalcitonin in patients with chronic renal insufficiency: a systematic review and metaanalysis. Nephrol Dial Transplant. 2013;28:122-9.
16. Gustafsson A, Ajeti V, Ljunggren L. Detection of suPAR in the saliva of healthy young adults: comparison with plasma levels. Biomark Insights. 2011;6:119-25.

17. Mondino A, Blasi F. UPA and UPAR in fibrinolysis, immunity and pathology. Trends Immunol. 2004;25(8):450-5.

18. Rijneveld AW, Levi M, Florquin S, Speelman P, Carmeliet $P$, van der Poll T. Urokinase receptor is necessary for adequate host defence against pneumococcal pneumonia. J Immunol. 2002;168(7):3507-11.

19. Wittenhagen P, Kronborg G, Weis N, Nielsen H, Obel N, Pedersen SS, et al. The plasma level of soluble urokinase receptor is elevated in patients with Streptococcus pneumoniae bacteraemia and predicts mortality. Clin Microbiol Infect. 2004;10:409-15.

20. Florquin S, van den Berg JG, Olszyna DP, Claessen N, Opal SM. Release of urokinase plasminogen activator receptor during urosepsis and endotoxemia. Kidney Int. 2001;59(6):2054-61.

21. Kofoed K, Andersen O, Kronborg G, Tvede M, Petersen J, Eugen-Olsen J, et al. Use of plasma C-reactive protein, procalcitonin, neutrophils, macrophage migration inhibitory factor, soluble urokinase-type plasminogen activator receptor, and soluble triggering receptor expressed on myeloid cells-1 in combination to diagnose infections: a prospective study. Crit Care. 2007;11(2):R38.

22. Mizukami IF, Faulkner NE, Gyetko MR, Sitrin RG, Todd RF 3rd. Enzyme-linked immune absorbent assay detection of a soluble form of urokinase plasminogen activator receptor in vivo. Blood. 1995;86(1):203-11.

23. Hayek SS, Sever S, Ko YA, Trachtman H, Awad M, Wadhani S, et al. Soluble Urokinase receptor and chronic kidney disease. N Engl J Med. 2015;373(20):1916-25.

24. Wei C, El Hinid S, Li J, Fornoni A, Goes N, Sageshima J, et al. Circulating urokinase receptor as a cause of focal segmental glomerulosclerosis. Nat Med. 2011;17:952-60.

25. Hahm E, Wei C, Fernandez I, Li J, Tardi NJ, Tracy M, et al. Bone marrowderived immature myeloid cells are a main source of circulating SUPAR contributing to proteinuric kidney disease. Nat Med. 2016;23:100-6.

26. Shankland SJ, Jefferson JA. A bone marrow factor contributes to kidney disease. Nat Med. 2017;23(1):13-4.

27. Mossanen JC, Pracht J, Jansen TU, Buendgens L, Stoppe C, Goetzenich A, et al. Elevated soluble urokinase plasminogen activator receptor and proenkephalin serum levels predict the development of acute kidney injury after cardiac surgery. Int J Mol Sci. 2017;18(8):E1662.

Ready to submit your research? Choose BMC and benefit from

- fast, convenient online submission

- thorough peer review by experienced researchers in your field

- rapid publication on acceptance

- support for research data, including large and complex data types

- gold Open Access which fosters wider collaboration and increased citations

- maximum visibility for your research: over $100 \mathrm{M}$ website views per year

At BMC, research is always in progress.

Learn more biomedcentral.com/submissions 